\title{
Can China rescue the global climate change negotiations?
}

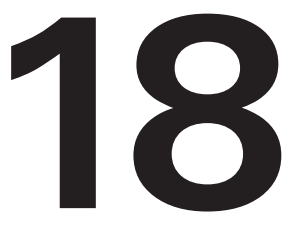

\section{Stephen Howes}

China has to make a substantial commitment, though I cannot say what exactly the nature of that commitment ought to be.

- Todd Stern, US special envoy for climate change ${ }^{1}$

\section{Introduction}

China's importance in global efforts to reduce greenhouse gas emissions is widely acknowledged. Greater efforts by China to reduce emissions will have large direct and indirect environmental benefits - direct because China is the world's largest emitter and indirect because China is a superpower. Greater efforts by China would induce greater effort by many other countries, developing and industrialised.

China already has policies in place to reduce emissions, including by improving energy efficiency and promoting renewable energy and afforestation (Sheehan and Sun 2008; Garnaut et al. 2008a; Information Office of the State Council 2008). Emissions have, however, grown rapidly in China in recent years: carbon dioxide emissions from fossil fuels - the main source of greenhouse gases - grew on average at 10.5 per cent per annum between 2000 and 2007 (Netherlands Environmental Assessment Agency 2008). Growth in emissions has slowed with the onset of the global recession, and perhaps even gone negative, but it is expected to pick up again with economic recovery. Continued growth of emissions in China at or close to 10 per cent per annum would offset any reduction in emissions in industrialised countries and would discourage global action. What, however, does the world expect of China? What might China agree to do? And what impact could China have on global climate change negotiations, which have been making little progress?

As the opening quote suggests, these are not easy questions. They are also risky questions to answer, since they are live, and the real answers - as 
against good guesses - might become apparent any day. There are, however, also no more important questions confronting the current round of global climate change negotiations. On these grounds of importance, rather than ease or prudence, I attempt in this chapter to provide an answer to these questions. I claim no special insider's knowledge on climate change policy in China, but rather draw on recently published material.

To provide the necessary context, I begin by summarising the history and status of international climate change negotiations. I then set out a range of non-official views that has emerged from China in recent months, consider their possible implications for official policy and conclude with an attempt to answer the questions set out above.

\section{Continuity and change in international climate change negotiations}

If serious international climate change mitigation does get under way in the coming years, the past decade (roughly 1998-2008) will be viewed as the lost decade for climate change. And, if serious international mitigation does not emerge, the mishaps of the past decade will be among the main reasons why.

After the Kyoto Protocol was concluded in December 1997, the US Administration, responding to the US Senate's Bryd-Hegel Resolution of July 1997, ${ }^{2}$ stated that it would not push for ratification of the treaty without developing countries doing more. As Todd Stern (1999), then President Bill Clinton's climate change coordinator, indicated in June: 'we are not...intending to submit the treaty for Senate ratification until we have a greater...meaningful level of participation from developing countries, which we don't yet have.'

The diplomatic 'full-court press' launched by then Secretary of State, Madeleine Albright (1998), in support of this objective achieved very little. In hindsight, it was mission impossible, since the United States was essentially trying to reopen an international agreement the ink on which was barely dry. Two developing countries, Argentina and Kazakhstan, expressed interest in voluntarily adopting emissions targets (Victor 2001). Overall, however, developing countries responded with hostile solidarity. China led the opposition. Liu Jiang, head of China's delegation to the Sixth Conference of the Parties under the UN Framework Convention on Climate Change (UNFCCC) in 2000 argued that: 
To confuse the different responsibilities between developed and developing countries, to impose new obligations on the latter and even take this as a condition for the Protocol's ratification, will lead to nothing but fierce political confrontations. This, undoubtedly, is a catastrophe for the international community in their efforts to combat climate change. (Liu 2000)

In the end, no developing countries adopted emissions targets. In 2001, under President George W. Bush, the United States announced that it would not be ratifying the Kyoto Protocol.

Fast forward to today and the US focus once again is on developing countries. Todd Stern, now the climate change envoy for President Barack Obama, summed up the current US position earlier this year:

I think the most fundamental issues in this negotiation in general have to do with how we think about, capture and express the actions and the level of undertakings to be taken by major developing countries as well as the developed countries. (Stern 2009)

China's response, a decade later, was also little changed. Developing countries were not the problem. Rather, 'the key to a deal in Copenhagen lies in the "political will" of the developed countries', according to Su Wei, China's chief climate change negotiator (Wu and Huan 2009).

To understand this decade-long stand-off, one has to return to the 1992 Framework Convention on Climate Change (UNFCCC). The UNFCCC, which has been ratified by 192 parties, including the United States, committed industrialised countries to move first, to take, as the preamble put it, 'immediate action... as a first step towards comprehensive response strategies at the global, national, and, where agreed, regional levels'. The Kyoto Protocol to the convention, with its commitment by industrialised countries to reduce emissions by 2008-12 by 5 per cent relative to 1990 levels, was intended to be this first step-but it was never taken. The failure of the United States to ratify the treaty dealt a fatal blow to the protocol's credibility and discouraged effort by those industrialised countries that did go ahead. Few have succeeded in achieving a sustained decline in emissions.

This 'first-step' strategy - let us call it Plan A — has now been discarded. From an environmental perspective, it is too dangerous for developing countries to continue to sit outside the international climate change 
mitigation regime. Whereas in 1990, developing-country carbon dioxide emissions from the combustion of fossil fuels were about one-quarter of total global emissions, by 2005, they were 40 per cent (IEA 2007a). In any case, the US response to Kyoto has made any first-step strategy politically untenable. Industrialised countries are therefore trying to move towards a Plan B, which involves all major emitters. Under Plan B, industrialised countries are still meant to do more (hence preserving the UNFCCC principle of common but differentiated responsibility), but no longer go first.

The slow progress being made in negotiations bears testimony to the difficulty of this task. Since industrialised countries didn't deliver on Plan $\mathrm{A}$ and since Plan B involves asking more of developing countries, it is not surprising that the transition is proving difficult and acrimonious. To use a colloquial expression, industrialised countries don't have a leg to stand on. Moreover, no country is prepared to reopen the UNFCCC itself, yet it is this treaty that commits industrialised countries not only to move first but, moreover, to compensate developing countries for the 'agreed full incremental costs' they will bear for any actions they should choose to take to mitigate climate change (Article 4.3). These provisions provide ample grounds for any developing country to object to any push to a Plan B that requires them to do more.

The distance the world has to cover to reach an agreement at Copenhagen or beyond can be seen from the disagreements in relation to the three main negotiating planks of the 'Bali Road Map', agreed in Bali, Indonesia, in December 2007. The various complexities and strands of the Bali Road Map can be boiled down to three main points (Howes 2009; de Boer 2009): ${ }^{3}$

- industrialised countries should commit to economy-wide emissions reduction targets

- developing countries should take 'nationally appropriate mitigation action'

- industrialised countries should provide financing and other support to developing countries for mitigation and adaptation.

While these three propositions command widespread agreement, the debate about each is intense. Concerning the first, all major industrialised countries have now indicated what their emissions reduction targets for 2020 will likely be. Initial analysis suggests that the likely aggregate 
industrialised-country reduction will be in the range of 10-20 per cent by 2020 from 1990 levels (Howes 2009). Developing countries, however, are demanding that industrialised countries cut emissions by at least 25-40 per cent, in line with numbers drawn from the Fourth Assessment Report of the Intergovernmental Panel on Climate Change (IPCC) and first floated at the Bali conference. Often, the demands are placed at the top end of that range. In its May 2009 submission to the UNFCCC, China called on '[a]ll developed country Parties to the Convention [to] commit to reduce their GHG emissions by at least 40\% below 1990 levels by 2020' (Government of the People's Republic of China 2009:63). ${ }^{4}$

There is a similarly sharp divergence of views in relation to the third issue. Developing countries argue that international funding should be provided largely through the public sector and needs to be large (in the range of hundreds of billions of dollars annually). China's May 2009 submission recently called on '[d]eveloped country Parties [to] make assessed contributions by a percentage of annual GDP, e.g. $0.5-1 \%$, in addition to the existing ODA' (Government of the People's Republic of China 2009:68). ${ }^{5}$ This would have to be public funding: 'Private sector approach[es] and market-based mechanism[s] can only play a complementary role in addressing climate change' (Government of the People's Republic of China 2009:68). Large funding claims by developing countries tend to be dismissed by industrialised countries as 'ambit claims' (Spiegel Online 2009). They are reluctant to fund mitigation in middleincome developing countries, including China, ${ }^{6}$ and argue that funding to developing countries to support their mitigation should be delivered largely by the private sector. The United States' May 2009 submission to the UNFCCC suggests that '[t]he private sector is expected to be a much larger source of funding than the public sector' (Government of the United States of America 2009:8).

The second issue, relating to mitigation actions to be taken by developing countries, is the most complex. The debate is currently about how these actions should be recorded and has not yet reached the more important issue of what they should add up to in terms of emissions reductions. There is agreement that developing countries will not be asked to sign on to binding targets (as industrialised countries will continue to be), but not much beyond that. In general, although there is a range of views among industrialised and developing countries, industrialised countries want developing countries to commit to plans of action, with quantification of the implied emissions reduction and strong international 
recognition. Developing countries on the other hand stress the voluntary and discretionary nature of the decision to mitigate, and the link to external financing.

The debate in relation to this second plank of the negotiations can be seen by positions put forward by the United States and South Africa. The United States, for example, has called for the new climate change agreement to include for industrialised countries, 'quantitative emissions reductions/ removals' by 2020 and, for developing countries, 'nationally appropriate mitigation actions [up to 2020]...that are quantified (e.g., reduction from business-as-usual)' (Government of the United States of America 2009:4). South Africa, in contrast, recommends that any new agreement contains provision for only a 'register of nationally appropriate mitigation actions by developing countries'. The register would

initially contain a list of indicative mitigation actions proposed and support needed to implement and will include information related to the assumptions and methodology underpinning the proposed action, the emissions that would be avoided, relative to baseline, and the required support for the indicative mitigation actions. (Government of South Africa 2009:97)

The register would be updated annually. The South African position thus accords developing-country actions a lower legal standing than industrialised-country commitments (only the latter would actually appear in the treaty) and links them more tightly to support from industrialised countries.

While the range of views in relation to it is large, it is this second plank of negotiations that represents the biggest hope of a way forward for the current round of climate change negotiations, since it suggests a convergence of views in an area in which disagreements a decade ago fatally undermined the Kyoto Protocol. In particular, it appears that the United States is not pursuing in this round binding emissions targets for developing countries. Industrialised countries are now broadly united in what they are seeking from developing countries - that is, commitments to policies and measures rather than to quantitative targets. The United States has been explicit about this in recent months, including through its recent submission to the UNFCCC and through public statements. For example on 12 June 2009, Jonathon Pershing, the US chief negotiator, was quoted as saying: 'We're saying that the actions of developing countries should be binding, not the outcomes of those actions' (Adam 
and Goldenberg 2009). In the same month, during his visit to China, Stern was reported as saying, 'We don't expect China to take a national cap at this stage' (You et al. 2009b).

This approach also suggests that developing countries are now prepared to do more. Developing countries in general might still be termed 'reluctant nations' when it comes to mitigation (Victor 2008), but they are certainly less reluctant than they used to be. Their position is expressed well in the G5 (Brazil, China, India, Mexico and South Africa) 2008 statement:

We, on our part, are committed to undertaking nationally appropriate mitigation and adaptation actions which also support sustainable development. We would increase the depth and range of these actions supported and enabled by financing, technology and capacity-building with a view to achieving a deviation from business-as-usual. (G5 2008)

Whereas the developing-country position embedded in the UNFCCC might be summarised as, 'We'll only mitigate if we want to, and if there is external financing', this new position could be summarised as 'We'll mitigate climate change on our own to some extent, and we will do more if there is external financing'.

This change in positions is for a number of reasons. On the part of the United States, it perhaps represents the lessons of experience. Getting developing countries to sign on to quantitative targets was tried in the late 1990s, and failed. On the part of the developing countries, there is no doubt that the risks of climate change are better appreciated today than they were 10 years ago. Recent projections for the melting of the HinduKush-Himalayan-Tibetan glacial system (the Earth's 'third pole') suggest that 75 per cent of it will have melted within 50 years, with potentially catastrophic impacts on lives and livelihoods across Asia (UNEP 2008). ${ }^{7}$ Having the United States back in the negotiating room at least makes a negotiated agreement possible. It also raises prospects of trade retaliation if an agreement isn't forthcoming, and puts the onus on leading developing countries - none more so than China - to be good global citizens.

China itself has said little in relation to this issue of developing-country mitigation action, though its position overall appears to be similar to that of South Africa (NDRC 2009). What domestic action, if any, China might commit to is the subject of the remainder of this chapter. 


\section{Views from China}

A number of Chinese papers have recently appeared in two distinct areas: global agreements and national targets. What follows below is not intended by any means to be an exhaustive survey, but rather an important sample of relevant arguments and positions.

Papers by Zhang et al. (DRC Project Team 2009), Pan et al. (2008a) and Cao (2008) have all taken up the issue of the desirable shape of a global agreement. All three argue for a global cap-and-trade regime in which China participates fully. Given China's traditional opposition to such a position, this itself makes the papers interesting. The status of the authors also demands that this body of work be taken seriously. The Development Research Centre (DRC) is the think tank of the National Development Research Council (NDRC), which has carriage of climate change policy in China. Professor Pan Jiahua is a distinguished scholar and adviser to the government on climate policy.

While the three proposals differ in various ways, they all argue that one factor that should be taken into account when the global emissions budget is divided between countries is cumulative per capita emissions. Garnaut (2008) shows that most of the industrialised-country targets for 2050 are broadly consistent with a gradual convergence by that date to equal current per capita emissions production. An approach that allocated emissions on per capita past rather than future emissions would, however, require much steeper cuts by industrialised countries. For example, by my calculations, the Pan et al. (2008a) paper has the implication that industrialised countries need to commit to emissions reductions of 65 per cent by $2020 .^{8}$

The second set of papers suggests domestic emissions and energy policy targets for China for the next decade. The Sustainable Development Strategy Report produced by the Chinese Academy of Sciences (CAS) in March 2009 proposes that

by 2020 , China's low carbon economic development target be set at $40 \%-60 \%$ reduction of energy consumption per unit of GDP over the 2005 level, and $\mathrm{CO}_{2}$ emissions per unit of GDP be decreasing by about $50 \%$. With support of reasonable and fair technology transfer and financing mechanism[s]...China's carbon emissions could be expected to peak between 2030 and 2040, and then stabilize and start to decline afterwards. (CAS 2009) 
A recent paper by Jiang Kejun and his co-authors of the Energy Research Institute (also part of the NDRC) projects a policy scenario in which energy intensity (the ratio of energy consumed to gross domestic product [GDP]) falls by 50 per cent between 2005 and 2020 (Jiang et al. 2009).

Finally, an article by Hu Angang (2009), of Tsinghua University and an adviser to the government, argues that China should peak its carbon dioxide emissions by 2020, return them by 2030 to 1990 levels and by 2050 reduce emissions to half of their 1990 levels.

What sort of impact might these academic analyses and arguments have on official Chinese policy? Given the consensus outlined in the previous section that developing countries will not be called on to take on binding targets at Copenhagen, the global agreement papers are likely to have more of an influence in the longer term. The curious compromise world of 'targets and timetables' for industrialised countries and 'policies and measures' for developing countries, which the international climate change regime appears to be heading for, is best understood as a transitional one. Ultimately, a more harmonised regime will need to prevail, if only for purposes of comparability. ${ }^{9}$ Perhaps more and more countries will take on economywide targets. If so, the arguments of the first set of papers indicate some of the difficulties the world might face making the transition. Industrialised countries, having already announced medium (2020) and long-term (2050) targets, have a first-mover advantage. Developing countries, however, when they come to accept quantitative targets, are unlikely to be prepared to derive their targets from the residual of an agreed global target and a set of pre-announced industrialised-country targets. They might also want a renegotiation of industrialised-country targets, along the lines of the arguments advanced by these three papers. ${ }^{10}$

The other set of papers seems more relevant for the short term and for the current negotiating framework. As foreshadowed in Garnaut (2008), could China use domestic policies as the basis for an international commitment to mitigate climate change?

China is now preparing its next five-year plan, which will run from 2011 to 2015. China already has a number of emissions and energy-related targets. There have recently been various suggestions from the media that China is gearing up to adopt new targets for the next five-year plan or possibly out to 2020. Media reports suggest that the existing goal for energy-efficiency improvement (a 20 per cent reduction in the energy 
intensity ratio over the period of the Eleventh Five-Year Plan from 2005 to 2010) could be extended out to 2015 or 2020 (Chen and Miles 2009). Indeed, China already has an implicit goal: the 2005 China National Energy Strategy and Policy 2020 (DRC 2005) sets a goal of quadrupling GDP by 2020 while only doubling energy use, implying a halving of energy intensity. Chinese officials have also recently indicated that the 2020 target for renewable energy could be increased from 15 per cent (NDRC 2007) to 20 per cent (AFP 2009). It has also been reported that a goal to reduce the carbon intensity of output might be adopted (Li 2009). Zhang Xiaoqiang, Vice-Chairman of the NDRC, was quoted in London as saying that 'Beijing was open to the idea of limits on the carbon intensity of its economy... We have taken note of some expert suggestions on carbon intensity with a view to have some quantified targets in this regard. We are carrying out a serious study of those suggestions' (Borger and Watts 2009).

Hu's (2009) recommendations appear to be unrealistic and, by recommending that by 2030 emissions be returned to their 1990 level, ask too much of China. To see this, note that in Garnaut (2008), even under a stringent 450 parts per million ( $\mathrm{ppm}$ ) global stabilisation agreement, China's emissions entitlements in 2030 are still about double their 2000 levels. Let us assume, however, that, in line with CAS (2009) and consistent with Jiang et al. (2009), China adopts an explicit policy of halving its carbon intensity by 2020 over 2005 through some combination of improvements in energy efficiency and increases in the share of renewable energy. This would require an annual average reduction in carbon intensity of about 4.5 per cent between 2005 and 2020 .

How ambitious this is depends on what is understood as the current trajectory of emissions. Views differ greatly on this. A halving of carbon intensity by 2020 would require a deviation - of 10 per cent below the Energy Information Administration (EIA 2009) reference case; 28 per cent below the reference case of the International Energy Agency (IEA 2007b); 30 per cent below the McKinsey Global Institute's (2007) projections; 37 per cent below the projections of Garnaut et al. (2008b); and 45 per cent below those of Sheehan and Sun (2008). ${ }^{11}$

Projecting China's trajectory of emissions is difficult for two reasons. First, the policy regime in China with regards to energy is complex and in flux, and it is difficult to estimate the effect of existing measures. As Sheehan and Sun (2008:404) comment, 'the government has relied mainly on "command and control" measures, rather than price or tax measures'. 
Second, there is a structural break in about 2000 in the long-term trend of energy intensity (Figure 18.1). It is difficult to know whether the flattening out of emissions intensity since 2000 is a temporary aberration or a new long-term trend. Garnaut et al. (2008b) argue that the historical experience of other developing countries, including rapidly growing Asian countries, suggests that, without policy action, little further decline in emissions intensity would be expected. This in turn would support the case that a target of halving emissions intensity by 2020 is indeed a very ambitious policy, representing a one-third or more deviation from outcomes in which energy efficiency and clean energy are not explicitly targeted.

\section{Figure 18.1 China's energy intensity, 1980-2008}

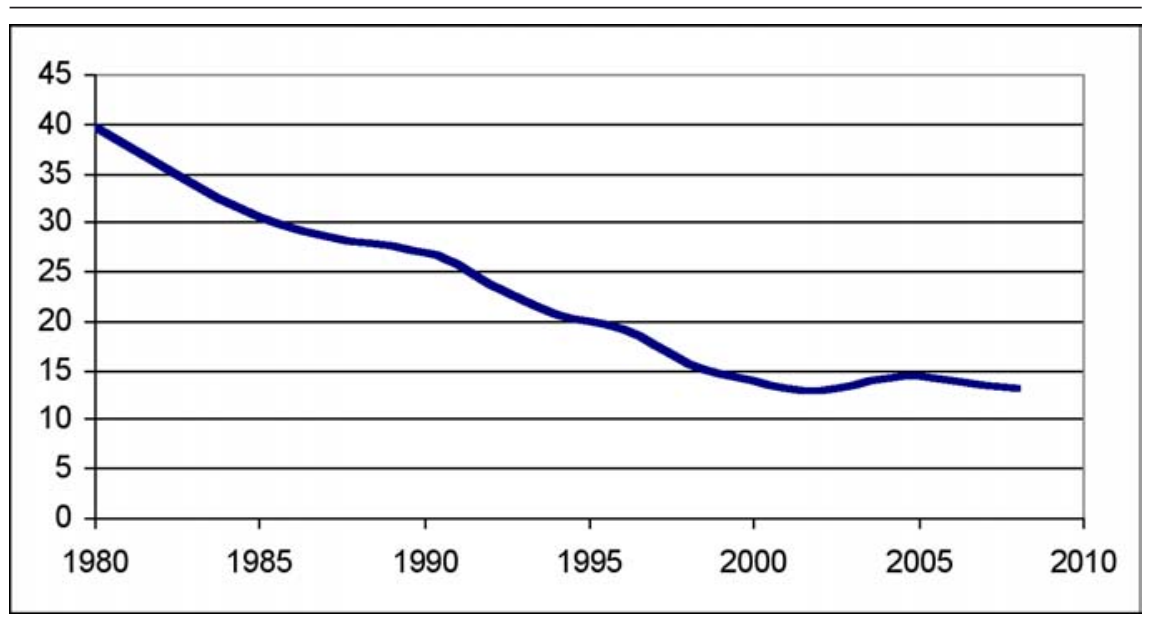

Note: The ratio is energy (in million tons of standard coal equivalent) over GDP (CNY billion at 2000 prices).

Sources: National Bureau of Statistics (NBS) 2008, China Statistical Yearbook 2008, China Statistics Press, Beijing, <http://www.stats.gov.cn/tjsj/ndsj/2008/indexeh.htm>; National Bureau of Statistics (NBS) 2009, Statistical communiqué of the People's Republic of China on the 2008 national economic and social development, National Bureau of Statistics, Beijing, < http://www.stats.gov.cn/english/newsandcomingevents/t20090226_402540784.htm >

Of course, it is important to stress that such a policy commitment implies that China's emissions will increase. How much depends on growth. With 8 per cent annual average growth to 2020, carbon dioxide emissions would grow by 70 per cent above 2005 levels even with a halving of emissions intensity in this period.

It is, however, equally important to realise that it is inevitable that China's emissions will continue to rise for some time. A one-third deviation from business-as-usual by 2020 is more than what is judged by most to 
be an equitable or reasonable contribution by China to a stabilisation agreement. For example, the Garnaut Review (Garnaut 2008) gave China headroom so that its emissions entitlement at 2020 under an ambitious (450ppm overshooting) global stabilisation scenario was only 10 per cent below business-as-usual. The influential analysis of den Elzen and Höhne (2008) suggests that developing-country emissions need to be only 15-30 per cent below business-as-usual in 2020 for the same scenario.

A policy commitment from China would need to be not only ambitious but credible. There is only space here for a preliminary analysis. So far, China has had limited success in achieving its 4 per cent annual reduction goal for energy intensity - the goal it would need to continue with for another decade to achieve a halving of its carbon intensity. By my calculations, based on the latest available statistics, China had achieved by the end of 2008 about only an 8 per cent reduction in energy intensity since the goal was launched in 2005 (Figure 18.2). ${ }^{12}$ That leaves it less than halfway to its 20 per cent target by 2010, with only two years to go. Moreover, most of the reduction was achieved in 2008 and as a result of the global recession (which has hit energy-intensive exports particularly hard) not of Chinese policy.

\section{Figure 18.2 Growth in energy intensity: recent performance and targets}

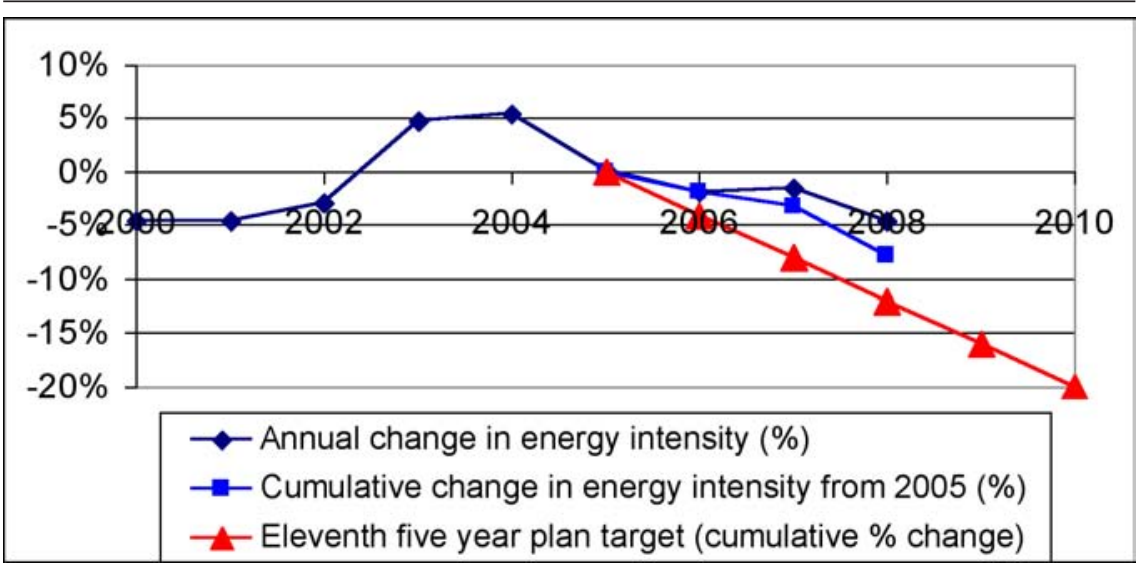

Sources: National Bureau of Statistics (NBS) 2008, China Statistical Yearbook 2008, China Statistics Press, Beijing, <http://www.stats.gov.cn/tjsj/ndsj/2008/indexeh.htm>; National Bureau of Statistics (NBS) 2009, Statistical communiqué of the People's Republic of China on the 2008 national economic and social development, National Bureau of Statistics, Beijing, <http://www.stats.gov.cn/english/newsandcomingevents/t20090226_402540784.htm>; see also Note 12 and the note to Figure 18.1. 
Meanwhile, China's energy mix shows stability, with increases since 2000 in the shares of coal and gas, a reduction in reliance on oil and no change in the share of nuclear and renewable energy (Figure 18.3). If we assume GDP grows at 8 per cent a year from now until 2020, and the energy intensity target is met, renewable energy will have to grow by about 9 per cent annually out to 2020 to meet the 15 per cent target, and by about 11 per cent annually to meet a 20 per cent target. If the share of coal, oil and gas remains constant, increasing the share of renewables to, say, 20 per cent will reduce the carbon intensity of energy by about 15 per cent. If the share of coal relative to oil and gas continues to increase, this will somewhat offset the impact of a rising renewable energy share.

\section{Figure 18.3 China's energy mix, 1990-2007 (per cent)}

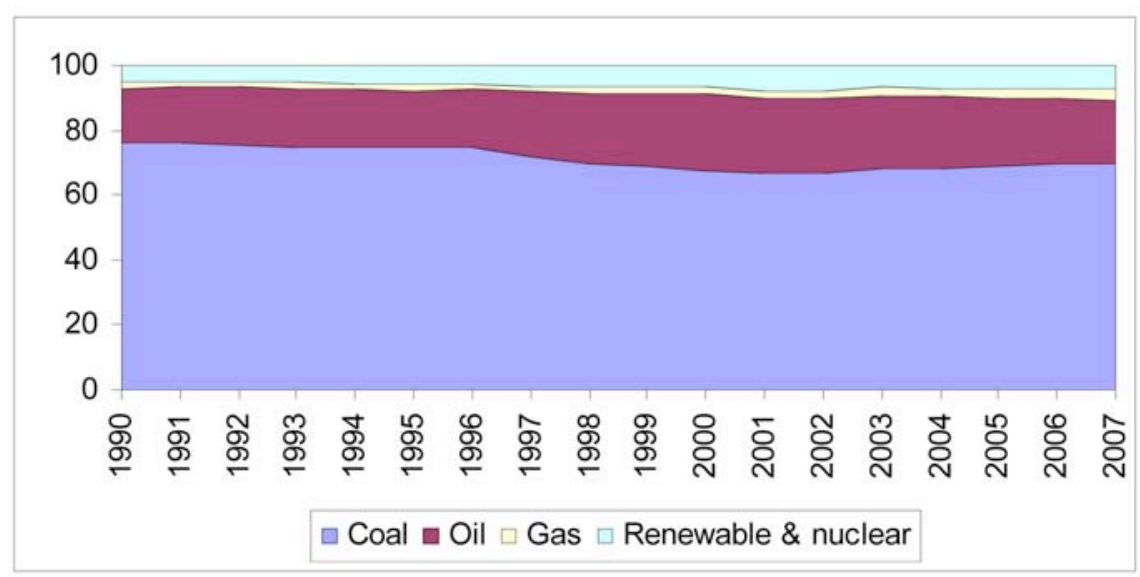

Source: National Bureau of Statistics (NBS) 2008, China Statistical Yearbook 2008, China Statistics Press, Beijing, <http://www.stats.gov.cn/tjsj/ndsj/2008/indexeh.htm >

Projections to 2020 (apart from the papers already cited, which obviously argue that a halving of emissions intensity is feasible) give a range of outcomes for what is possible under a reform scenario. A 50 per cent reduction in emissions intensity by 2020 lies about 20 per cent below the policy scenarios of the 2007 IEA projections and Sheehan and Sun (2008). ${ }^{13}$ The McKinsey Global Institute's projections are typically more optimistic than others about how quickly energy efficiency can be improved. A 50 per cent reduction target is, however, about 10 per cent below what the McKinsey Global Institute (2007) estimates can be achieved using existing technologies in profitable energy-efficiency improvements, though note that the McKinsey projections are in terms of energy efficiency alone, and 
the targeted increases in renewable energy would further reduce China's carbon intensity, as discussed above.

In summary, a target for 2020 that aimed broadly at halving China's carbon intensity from its 2005 level would certainly be seen as ambitious. Indeed, the United States has already effectively said as much, with its chief negotiator commenting, in the context of a possible goal for China for the next five years, '[i]f they come up with improvements in energy efficiency, then 20 percent would be an excellent number, a very strong number' (Spiegel Online 2009). ${ }^{14}$ Indeed, the target is so ambitious that some might view it as not credible, especially given China's limited success in recent years in reducing energy intensity. Nevertheless, other countries will want to encourage China to adopt an ambitious target rather than cautioning it against making an offer it might not achieve. ${ }^{15}$ The direction of policy in China is clear, and the expectation is that an ambitious target would itself provide the impetus for more sweeping reforms in China, including possibly the introduction of widespread carbon pricing.

For China to provide a stimulus to international negotiations, it will need to not only announce a target along these lines but be prepared to make an international commitment to it. If China is not prepared to make a quantitative commitment along the lines expected of industrialised countries, it will need to commit to, say, the halving of emissions intensity as a quantitative, non-binding indicator of what its policies are expected to deliver. Once an international commitment was made, some sort of international monitoring would be expected. If China is not planning to seek international funding for this commitment, then its recent statements suggest that it won't accept international monitoring (NDRC 2009). ${ }^{16}$ By the same token, it seems unlikely that, if agreement was in sight, a compromise would not be possible on this issue.

\section{Conclusion}

Amid the generally gloomy prospects for climate change negotiations and slow progress in relation to the same, this chapter has drawn attention to the possibility that China will commit to something like a halving of its carbon intensity between 2005 and 2020 .

This is far from a sure thing. We still can't say exactly what China will commit to, but we are also not completely in the dark. It is highly likely that China will continue with its energy-efficiency improvement program 
and it seems quite possible that it will combine this and its renewable energy program into a carbon-intensity (emissions-to-GDP) reduction target for 2015 or 2020. A target to halve emissions intensity by 2020 would clearly meet, if not exceed, the expectations of the industrialised countries. It would be seen as an ambitious, stretch target-possible but not easy to achieve. If put forward as an international commitment - as a quantified, non-binding indicator of expected policy impact - it would more than satisfy the expectations of industrialised countries. ${ }^{17}$

There are various reasons why China might adopt such a target but not be prepared to offer it as an international obligation. Agreement on the form in which such commitments should be made might not be possible. As mentioned, even though there would be no penalties for non-compliance, China might not be prepared to submit to international monitoring and reporting. There is also the large divide between what China is asking from the industrialised countries and what they are offering. The second section of this chapter indicated the huge gaps here in relation to emissions reduction targets and public funding.

Even if the distance between the negotiating parties is too great to be covered in the next few years, and no international agreement is possible, the recent policy developments in China are encouraging. Motivated by concerns about energy security and local air pollution as well as climate change, China appears likely to proceed with the sort of energy-efficiency and clean-energy policies analysed in this chapter regardless of whether an international treaty is in place or not. If the United States passes cap-andtrade legislation, the need for an international agreement to drive national action will be further reduced. The combined example of the world's two superpowers will be much more influential than the penalty provisions of any multilateral treaty. This provides a useful contingency in the event that no treaty can be negotiated or if, once again, the US Senate refuses to ratify any successor treaty. More generally, given the obstacles that will have to be overcome before a successful agreement can be reached, the more countries are committed to national action irrespective of their international obligations, the better will be the outlook for successful international climate change mitigation.

That said, there can be no doubt that the forging of an international agreement would give an important stimulus to domestic action around the world, and in particular would allow industrialised and developing countries to proceed with an understanding that each was doing its agreed 'fair share'. An international offer from China to halve its carbon intensity 
by 2020, in return for the West doing more in terms of emissions reduction and public funding - while itself a long shot - seems to be the best basis we have for a global deal. While a number of papers have recently called for US-China collaboration on climate change, conceived primarily in technological terms (Chandler 2008; Chu and Thornton 2009; Lieberthal and Sandalow 2009), collaboration on striking a global deal on these terms would be far more influential in unlocking the impasse that has long held back global climate change negotiations.

\section{References}

Note: All web references are current as of 16 June 2009.

Adam, D. and Goldenberg, S. 2009, 'US says it will not demand binding carbon cuts from China', The Guardian, 12 June 2009, $<$ http://www.guardian.co.uk/environment/2009/jun/12/climatechange-copenhagen $>$

Agence France-Presse (AFP) 2009, 'China eyes 20 pct renewable energy by 2020: report', Agence France-Presse, <http://www.google.com/ hostednews/afp/article/ALeqM5iHms-GqSyTR6Yu7xFhZY8nf7IzlQ>

Albright, M. K. 1998, Earth Day 1998: global problems and global solutions, Press release, US Department of State, Washington, DC, $<$ http://secretary.state.gov/www/statements/1998/980421.html>

Borger, J. and Watts, J. 2009, 'China launches green power revolution to catch up on West', The Guardian, 9 June 2009, <http://www.guardian. co.uk/world/2009/jun/09/china-green-energy-solar-wind >

Bradley, R. and Pershing, J. 2009, 'Introduction to sustainable development policies and measures', in K. Baumert and R. Bradley (eds), Growing in the Greenhouse, World Resources Institute, Washington, DC.

Cao, J. 2008, Reconciling human development and climate protection: perspectives from developing countries on post-2012 international climate change policy, Discussion Paper 2008-25, Harvard Project on International Climate Agreements, Cambridge, Mass.

Chandler, W. 2008, Breaking the suicide pact: US-China cooperation on climate change, Carnegie Endowment Policy Brief, Carnegie Endowment, Washington, DC. 
Chen, E. and Miles, T. 2009, 'China may extend energy-saving goal to 2020: paper', Reuters, 15 May 2009, <http://www.reuters.com/article/ rbssEnergyNews/idUSPEK2745720090515>

Chinese Academy of Sciences (CAS) 2009, Sustainable Development Strategy Report, Chinese Academy of Sciences, Beijing, $<$ http://www.theclimategroup.org/assets/resources/CAS_2009_ Sustainable_Development_Strategy_Report_-_Exec_Summary.pdf $>$

Chu, S. and Thornton, J. 2009, A Roadmap for US-China Cooperation on Energy and Climate Change, Pew Center and Asia Society's Center on US-China relations, Arlington, Va., and Washington, DC.

de Boer, Y. 2009, 2009: the year of climate change, Press release, United Nations Framework Convention on Climate Change, Bonn, Germany, $<$ http://unfccc2.meta-fusion.com/kongresse/090601_SB30_Bonn/ downl/090608_UNFCCC_Executive_Secretary.pdf>

den Elzen, M. and Höhne, N. 2008, 'Reductions of greenhouse gas emissions in Annex I and non-Annex I countries for meeting concentration stabilization targets: an editorial comment', Climatic Change, vol. 91, pp. 249-74.

Development Research Center of the State Council (DRC) 2005, China National Energy Strategy and Policy 2020, Development Research Center of the State Council, Beijing, <http://www.efchina.org/FReports. do?act $=$ detail\&id $=155>$

Development Research Center of the State Council Project Team (DRC Project Team) 2009, 'Greenhouse gas emissions: a theoretical framework and global solution', Economic Research Journal, [in Chinese], no. 3 (March).

Energy Information Administration (EIA) 2009, International Energy Outlook 2009, Energy Information Administration, US Department of Energy, Washington, DC, <www.eia.doe.gov/oiaf/ieo/index.html>

G5 2008, G5 statement issued by Brazil, China, India, Mexico and South Africa, 2008 Hokkaido Toyako Summit, Japan, 7-9 July 2008, $<$ http://www.twnside.org.sg/title2/climate/info.service/climate. change.20080702.htm>

Garnaut, R. 2008, The Garnaut Climate Change Review, Cambridge University Press, Cambridge. 
Garnaut, R., Jotzo, F. and Howes, S. 2008a, 'China's rapid emissions growth and global climate change policy', in L. Song and W. T. Woo (eds), China's Dilemma: Economic growth, the environment and climate change, ANU E Press and Asia Pacific Press, Canberra.

Garnaut, R., Jotzo, F. Howes, S. and Sheehan, P. 2008b, 'Emissions in the Platinum Age: the implications of rapid development for climate change mitigation', Oxford Review of Economic Policy, vol. 24, no. 2, pp. $1-25$.

Government of the People's Republic of China 2009, 'Submission to the UNFCCC ad hoc Working Group on Long-term Cooperative Action under the Convention', Ideas and Proposals on the Elements Contained in Paragraph 1 of the Bali Action Plan Submissions from Parties. Part I, FCCC/AWGLCA/2009/MISC.4 (Part I) (19 May), United Nations Framework Convention on Climate Change, Bonn, Germany.

Government of South Africa 2009, 'Submission to the UNFCCC ad hoc Working Group on Long-term Cooperative Action under the Convention', Ideas and Proposals on the Elements Contained in Paragraph 1 of the Bali Action Plan Submissions from Parties. Part II, FCCC/ AWGLCA/2009/MISC.4 (Part II) (19 May), United Nations Framework Convention on Climate Change, Bonn, Germany.

Government of the United States of America 2009, US Submission on Copenhagen Agreed Outcome, Government of the United States of America, Washington, DC, <http://www.state.gov/documents/ organization/124313.pdf>

Howes, S. 2009, 'Finding a way forward: three critical issues for a post-Kyoto global agreement on climate change', Indian Growth and Development Review, vol. 2, no. 1, pp. 75-98.

$\mathrm{Hu}$, A. 2009, 'A new approach at Copenhagen', China Dialogue, 6 April 2009, <http://www.chinadialogue.net/article/show/single/en/2892>

International Energy Agency (IEA) 2007a, $\mathrm{CO}_{2}$ Emissions from Fuel Combustion: 1971-2005, International Energy Agency, Paris.

2007b, World Energy Outlook 2007: China and India insights, International Energy Agency, Paris.

Information Office of the State Council 2008, China's Policies and Actions for Addressing Climate Change, Information Office of the State Council, Beijing, <http://www.ccchina.gov.cn/WebSite/CCChina/UpFile/File419.pdf> 
Jiang, K., Hu, X., Zhuang, X., Liu, H. and Liu, Q. 2009, Fuel substitution and diversification in China, Paper presented at ERI-ANU China Energy Conference, Canberra, 14 April 2009.

Li, J. 2009, 'Environmentally-sound tech needed', China Daily, 4 May 2009, <http://www.chinadaily.com.cn/bizchina/2009-05/04/ content_7740693.htm>

Lieberthal, K. and Sandalow, D. 2009, Overcoming obstacles to USChina cooperation on climate change, John L. Thornton China Center Monograph Series, John L. Thornton China Center at The Brookings Institution, Washington, DC.

Liu, J. 2000, Statement by H. E. Mr Liu Jiang, Head of the Chinese Delegation, Minister and Vice-Chairman of State Development Planning Commission of China, Sixth Conference of the Parties to the UNFCCC, $<$ http://www.ccchina.gov.cn/en/NewsInfo.asp?NewsId=5369>

McKinsey Global Institute 2007, Leapfrogging to Higher Energy Productivity in China, McKinsey Global Institute, Washington, DC.

National Bureau of Statistics (NBS) 2008, China Statistical Yearbook 2008, China Statistics Press, Beijing, <http://www.stats.gov.cn/tjsj/ ndsj/2008/indexeh.htm>

2009, Statistical communique of the People's Republic of China on the 2008 national economic and social development, National Bureau of Statistics, Beijing, <http://www.stats.gov.cn/english/ newsandcomingevents/t20090226_402540784.htm>

National Development and Reform Commission (NDRC) 2007, Medium and Long-Term Development Plan for Renewable Energy in China, [Abbreviated version, English draft], National Development and Reform Commission, Beijing, <http://www.martinot.info/China_RE_ Plan_to_2020_Sep-2007.pdf>

2009, 'Implementation of the Bali Roadmap: China's position on the Copenhagen Climate Change Conference', China Climate Change InfoNet, <http://www.ccchina.gov.cn/en/NewsInfo.asp?NewsId=17528>

Netherlands Environmental Assessment Agency 2008, Global $\mathrm{CO}_{2}$ Emissions: Increase continued in 2007, Netherlands Environmental Assessment Agency, Bilthoven, The Netherlands, <http://www.pbl.nl/ en/publications/2008/GlobalCO2emissionsthrough2007.html> 
Pan, J., Chen, Y., Wang, W. and Li, C. 2008a, Carbon budget proposal: global emissions under carbon budget constraint on an individual basis for an equitable and sustainable post-2012 international climate regime, Working Paper, December, Research Centre for Sustainable Development, Chinese Academy of Social Sciences, Beijing.

Pan, J., Phillips, J. and Chen, Y. 2008b, 'China's balance of emissions embodied in trade: approaches to measurement and allocating international responsibility', Oxford Review of Economic Policy, vol. 24, no. 2, pp. 354-76.

Sheehan, P. and Sun, F. 2008, 'Emissions and economic development: must China choose', in L. Song and W. T. Woo (eds), China's Dilemma: Economic growth, the environment and climate change, ANU E Press and Asia Pacific Press, Canberra.

Spiegel Online 2009, 'US wants a "legally binding climate agreement"', Interview with Jonathan Pershing conducted by Christian Schwägerl, Spiegel Online, <http://www.spiegel.de/international/ world/0,1518,630073,00.html>

Stern, T. 1999, Press briefing by Todd Stern, US President's Coordinator for Climate Change, <http://www.presidency.ucsb.edu/ ws/index.php?pid $=47854>$

2009, Press briefing of the US Delegation to the UNFCCC Climate Change Talks, Bonn, Germany, US Department of State, $<$ http://germany.usembassy.gov/events/2009/mar-29-stern/>

United Nations Environment Program (UNEP) 2008, Atmospheric Brown Clouds: Regional assessment report with focus on Asia, United Nations Environment Program, Nairobi, Kenya.

Victor, D. 2001, The Collapse of the Kyoto Protocol and the Struggle to Slow Global Warming, Princeton University Press, Princeton, NJ.

2008, Climate accession deals: new strategies for taming growth of greenhouse gases in developing countries, Discussion Paper, no. 2008-18, Harvard Project on International Climate Agreements, Cambridge, Mass.

Wu, L. and Huan, G. 2009, 'Top Chinese negotiator urges developed countries to commit more in fighting climate change', Xinhua, 1 April 2009, $<$ http://news.xinhuanet.com/english/2009-04/01/content_11109345.htm> 
You, N., Li, J. and Fu, J. 2009, 'US will not seek cap on emissions', China Daily, 11 June 2009, <http://www.chinadaily.com.cn/bizchina/2009-06/11/ content_8272942.htm>

\section{Acknowledgments}

I would like to thank Frank Jotzo and Ross Garnaut for their comments, as well as participants at two ANU seminars at which earlier versions of this chapter were presented, and Harry Guinness for his research assistance. All remaining errors are my own.

\section{Endnotes}

1. 'Climate envoy's cooperation call', China Daily, 23 February 2009, <http://www.china.org. cn/environment/news/2009-02/23/content_17318608.htm>

2. The Byrd-Hegel Resolution, which was passed 95-0, expressed the sense of the US Senate that the United States should not be a signatory to any protocol that would '(A) mandate new commitments to limit or reduce greenhouse gas emissions for the Annex I Parties, unless the protocol or other agreement also mandates new specific scheduled commitments to limit or reduce greenhouse gas emissions for Developing Country Parties within the same compliance period, or (B) would result in serious harm to the economy of the United States'.

3. The argument here is not that these three points provide the basis for the most efficient or effective global agreement, but rather they constitute the most likely basis for a global agreement. de Boer (2009) lists four points. The fourth relates to the governance of funding provided under the third point.

4. A related disagreement is about whether these targets should be met only by domestic emission reductions, as developing countries tend to argue, or by continued use of the Kyoto Protocol flexibility mechanisms, such as international trading and international offsets (the Clean Development Mechanism), as industrialised countries tend to argue.

5. ODA is official development assistance, or aid.

6. 'The convention talks about obligations that might total $\$ 100$ billion for activities like mitigation. But if you take a look at that, it includes all the mitigation requirements in China, South Korea and Singapore. These are not countries that need financial assistance from the rest of the world to mitigate. After you take those out, you have a much smaller number' (Spiegel Online 2009).

7. Although note that the latest scientific analysis suggests that blame for this should be shared equally between global warming due to greenhouse gases and regional warming of the lower atmosphere as well as soot deposition on snow and ice due to Asia's 'atmospheric brown cloud'.

8. Pan et al. (2008a) assume 40 per cent domestic cuts by 2020 over 2005 for Annex 1 countries and show Annex 1 countries still need to purchase 40 per cent of permits. This corresponds with a commitment to a 64 per cent cut by 2020 over 2005 ( 40 per cent domestic and $0.4^{*} 40$ per cent by permits). Similar calculations by India have led them recently to suggest 80 per 
cent cuts by industrialised countries by 2020 ('Japan, Russia urged to issue 2020 greenhouse goals', Reuters, 2009, <htp://www.alertnet.org/thenews/newsdesk/L8653677.htm>).

9. Many economists make a case on efficiency grounds for a 'top-down' harmonised regime, with all countries subject to either emissions targets or similar policies, such as carbon taxes. Others argue for a more 'bottom-up' approach to promote participation and compliance. As discussed in Howes (2009), the approach now being developed - 'top down' for industrialised countries with emissions targets and 'bottom up' for developing countries with country-specific policies - has no real foundation in the literature (though it is perhaps best captured by the idea of 'sustainable development policies and measures'; Bradley and Pershing 2005). Indeed, it has little by way of theoretical rationale, but appears rather to be emerging as a compromise between industrialised and developing blocs.

10. The other issue that China might raise should it opt to participate in an emissions target regime is whether targets should be set on the basis of production (as under Kyoto) or on the basis of consumption, which would favour China given its role as the world's manufacturer. See Pan et al. (2008b) for further discussion.

11. In some cases, no explicit projection for 2020 is given. In these cases, interpolation between, for example, 2015 and 2030 projections was used. The McKinsey Global Institute's base is 2003. The McKinsey figures are for energy intensity; the others are for carbon intensity.

12. A cumulative 7.7 per cent reduction is less than what is reported by China-for example, 10.1 per cent ('China's economy transforming in green revolution', Xinhua, 2009, <http:// www.cchina.gov.cn/en/NewsInfo.asp?NewsId=17836>). My figure is obtained by combining data from the China Statistical Yearbook 2008 (NBS 2008) with more recent data from the 2009 Statistical communiqué (NBS 2009). The more recent data pertain to output (from 2006 onwards) and to energy consumption (for 2008 only).

13. The IEA's 'alternative policy scenario' is based on environmental policies for China under consideration at the time the scenario was constructed (2007). Sheehan and Sun's most ambitious policy case is used for this comparison, in which the role of energy-intensive industries is reduced, relative energy prices increase and energy intensities improve in industry and transport. As earlier, interpolation is used to construct 2020 values when they are not available. The McKinsey base is 2003 .

14. This chapter focuses on a possible commitment to halve the carbon intensity of output by 2020 over 2005 levels. If the carbon intensity of energy is constant, halving of carbon intensity requires a halving of energy intensity. Achieving this for the period 2005-20 would be consistent with reducing energy intensity by 20 per cent over each of the fiveyear periods, 2005-10, 2011-15 and 2015-20.

15. This is especially true given the generally poor track record of industrialised countries in meeting their own Kyoto targets.

16. 'Only those actions enabled by measurable, reportable and verifiable support are subject to the "measureable, reportable and verifiable" requirement' (NDRC 2009).

17. The United States' May 2009 submission to Copenhagen indicates that it also would want major developing countries to commit to a peaking year for emissions and to indicate in which year they would take on binding emissions targets. Whether China would make commitments along these lines remains to be seen. Compromises will, however, also likely be forthcoming in the face of an ambitious offer from China. 